\title{
ANALISIS KETERKAITAN SIKAP DAN PENGETAHUAN PASIEN HIPERTENSI TERHADAP KEPATUHAN PENGGUNAAN OBAT ANTI HIPERTENSI DI RUMAH SAKIT ISLAM PURWODADI
}

\author{
Agustina Ratna Wulandari ${ }^{*}$, Delia Paramita $^{1}$, Eleonora Maryeta Toyo $^{1}$ \\ ${ }^{1}$ Sekolah Tinggi Ilmu Farmasi Nusaputera Semarang \\ Email: ratnawulandari268@gmail.com
}

ABSTRAK

Hipertensi merupakan penyakit yang memiliki angka prevalensi yang tinggi. Hipertensi dapat distabilkan dengan melakukan pola hidup yang sehat dan menggunakan obat anti hipertensi. Penggunaan obat antihipertensi diperlukan kepatuhan agar hipertensi dapat terkontrol. Kepatuhan pasien dalam melaksanakan pengobatan harus dipertahankan dalam jangka waktu yang lama, oleh sebab itu pasien harus memiliki pengetahuan yang baik dan sikap yang positif terhadap hipertensi. Tujuan penelitian ini adalah untuk mengetahui hubungan sikap dan pengetahuan pasien hipertensi terhadap kepatuhan peggunaan obat anti hipertensidi Rumah Sakit Islam Purwodadi. Penelitian ini menggunakan metode sensus dengan rancangan Cross Sectional. Desain ini digunakan untuk meneliti suatu kejadian dalam waktu yang bersamaan atau dalam sekali waktu. Teknik sampling dalam penelitian ini menggunakan metode sensus. Instrumen penelitian yang digunakan berupa kuesioner. Analisis data yang digunakan adalah analisis univariat dan bivariat. Dari analisis univariat didapatkan hasil 65\% responden memiliki sikap yang baik, $70 \%$ responden memiliki tingkat pengetahuan yang baik, serta 55\% responden memiliki kepatuhan minum obat antihipertesi yang tinggi. Pada analisis bivariat dengan uji statistik Chi Square $\alpha 0,05$ didapatkan hasil bahwa ada hubungan antara sikap dan kepatuhan minum obat antihipertensi ( $p$ value $=0,005)$, dan terdapat hubungan antara tingkat pengetahuan dan kepatuhan minum obat antihipertensi di Rumah Sakit Islam Purwodadi $(p$ value $=0,021)$.

Kata kunci: hipertensi, pengetahuan, sikap, kepatuhan, antihipertensi

\section{ABSTRACT}

Hypertension is a disease that has a high prevalence rate. Hypertension can be stabilized by adopting a healthy lifestyle and using antihypertensive drugs. The use of antihypertensive drugs requires compliance so that hypertension can be controlled. Patient compliance in carrying out treatment must be maintained in the long term, therefore patients must have good knowledge and positive attitudes towards hypertension. The purpose of this study was to determine the relationship between attitudes and knowledge of hypertensive patients on adherence to the use of antihypertensive drugs at Purwodadi Islamic Hospital. This study uses the census method with a cross sectional design. This design is used to examine an event at the same time or at one time. The sampling technique in this study used the census method. The research instrument used was a questionnaire. The data analysis used was univariate and bivariate analysis. From the univariate analysis, it was found that $65 \%$ of respondents had a good attitude, $70 \%$ of respondents had a good level of knowledge, and 55\% of respondents had high adherence to taking antihypertensive drugs. In bivariate analysis with Chi Square statistic $<0.05$, the results showed that there was a relationship between attitudes and adherence to taking antihypertensive drugs ( $\mathrm{p}$ value $=0.005$ ), and there was a relationship between the level of knowledge and adherence to taking antihypertensive drugs at Purwodadi Islamic Hospital ( $\mathrm{p}$ value $=0.021$ ).

Keywords: hypertension, knowledge, attitude, compliance, antihypertensive

PENDAHULUAN

Hipertensi adalah gangguan vaskular yang ditandai dengan tekanan darah sistolik sama dengan atau diatas $140 \mathrm{mmHg}$ dan atau tekanan darah diastolik sama dengan atau diatas $90 \mathrm{mmHg}$. Hipertensi sering tidak menimbulkan gejala sehingga juga disebut sillent killer. Hipertensi tidak menimbulkan gejala kepada penderita, namun bukan berarti tidak berbahaya, dalam jangka waktu yang lama dapat menimbulkan komplikasi. Oleh sebab itu, hipertensi dideteksi dini dengan pemeriksaan tekanan darah secara berkala (Depkes RI, 2012).

Hipertensi merupakan suatu penyakit dengan angka mortalitas dan morbiditas yang sangat tinggi di dunia. Penyakit hipertensi telah menjadi masalah utama dalam kesehatan masyarakat yang ada di Indonesia maupun di beberapa Negara yang ada di dunia. Diperkirakan sekitar $80 \%$ kenaikan kasus hipertensi terutama di Negara berkembang tahun 2025 dari sejumlah 639 juta kasus di tahun 2000, diperkirakan menjadi 1,15 milyar kasus di tahun 2025 (Sinuraya et al, 2018).

Secara teori terdapat dua terapi yang dilakukan untuk mengobati hipertensi yaitu terapi non farmakologis dan terapi farmakologis. Terapi non farmakologis dapat dilakukan dengan modifikasi gaya hidup yang meliputi berhenti merokok, melakukan diet berat badan, menghindari alkohol, serta yang mencakup psikis antara lain menghindari stress, melakukan olahraga, dan istirahat yang cukup. Secara farmakologis terapi dilakukan menggunakan obat-obatan antihipertensi yang dapat menurunkan tekanan darah. Golongan obat antihipertensi antara lain beta blocker, angiotensin II receptor blocker (ARB), angiostensin converting enzyme inhibitor (ACEI), diuretic, dan calcium channel blocker dianggap sebagai obat antihipertensi (Soenarto et al, 2015).

Kepatuhan minum obat antihipertensi sangat penting karena dengan minum obat antihipertensi secara teratur dapat mengontrol tekanan darah penderita hipertensi, sehingga dalam jangka panjang resiko kerusakan organ-organ penting tubuh seperti jantung, ginjal, dan otak dapat dikurangi. Oleh karena itu, diperlukan pemilihan obat yang tepat agar dapat meningkatkan kepatuhan dan mengurangi risiko kematian (Gama et al, 2014). 
Kepatuhan dalam suatu sikap merupakan respon yang hanya muncul apabila individu tersebut dihadapkan pada suatu stimulus yang menghendaki adanya reaksi individual. Kepatuhan adalah suatu sikap yang akan muncul pada seseorang yang merupakan suatu reaksiterhadap sesuatu yang ada dalam peraturan yang harus dijalankan (Notoatmodjo, 2014). Kepatuhan merupakan hal yang sangat penting dalam perilaku hidup sehat. Kepatuhan meminum obat antihipertensi adalah mengonsumsi obat-obatan yang diresepkan dokter pada waktu dan dosis yang tepat. Pengobatan hanya akan efektif apabila pasien mematuhi aturan dalam penggunaan obat (Danusantoso, 2012). Keberhasilan pengobatan hipertensi sangat dipengaruhi akan kepatuhan dalam berobat dan permasalahan kepatuhan pasien penyakit hipertensi banyak dipengaruhi faktor. Faktor yang dapat memengaruhi memengaruhi tingkat kepatuhan seseorang untuk meminum obat, yaitu : usia, pekerjaan, waktu luang, pengawasan, jenis obat, dosis obat, pengetahuan, sikap, dan penyuluhan dari petugas kesehatan (Darmanto, 2014). Tujuan dari penelitian ini adalah untuk mengetahui hubungan antara sikap dan pengetahuan pasien hipertensi terhadap kepatuhan penggunaan obat antihipertensi di Rumah Sakit Islam Purwodadi. Lokasi penelitian dilakukan di Rumah sakit Islam Purwodadi dengan pertimbangan bahwa terdapat kecenderungan yang meningkat jumlah pasien hipertensi di rumah sakit tersebut dan belum ada penelitian yang megkaji terkait dengan judul penelitian ini.

\section{METODE PENELITIAN}

Penelitian ini dilakukan pada bulan Februari sampai bulan April 2021 di Rumah Sakit Islam Purwodadi. Metode Penelitian yang digunakan yaitu sensus dengan rancangan pendekatan kuantitatif analitik dan Cross sectional. Instrumen yang digunakan berupa kuesioner yang diberikan pada masing-masing responden yang menjadi sampel. Kuesioner Kuesioner disusun mengacu pada teori sikap dan pengetahuan pasien (Notoatmojo, 2005). Pada penelitian ini sampel yang digunakan yakni seluruh populasi karena jumlah unit sampling dalam populasi tidak terlalu besar atau relative sedikit yaitu semua pasien rawat jalan yang melakukan pengobatan hipertensi di Rumah Sakit Islam Purwodadi.

Hipotesis yang dirumuskan dibuktikan dengan menggunakan analisis bivariat yaitu uji chi square yang bertujuan untuk mengetahui hubungan antara variable.

Uji validitas dan reliabilitas dilakukan dengan menggunakan uji korelai product moment pearson dan Cronbach alpha. Hasil pengujian menunjukkan hasil bahwa item kuesioner yang digunakan adalah valid dan reliabel.

\section{HASIL DAN PEMBAHASAN}

Berdasarkan teknik penelitian yang digunakan pada penelitian ini yakni metode sensus sehingga seluruh populasi dijadikan sampel maka didapat hasil sebanyak 20 pasien yang dijadikan responden. Hasil pengumpulan kuesioner didapatkan data karakteristik pasien hipertensi meliputi jenis kelamin, usia, pendidikan, dan pekerjaan dapat dilihat pada Tabel 1 .

Tabel 1. Karakteristik Responden

\begin{tabular}{|c|c|c|}
\hline Karakteristik & Frekuensi & $\begin{array}{c}\text { Persentase } \\
(\%)\end{array}$ \\
\hline \multicolumn{3}{|l|}{ Jenis kelamin } \\
\hline Laki-laki & 9 & 45 \\
\hline Perempuan & 11 & 55 \\
\hline Total & 20 & 100 \\
\hline \multicolumn{3}{|l|}{ Umur } \\
\hline $17-23$ & 1 & 5 \\
\hline $24-30$ & 2 & 10 \\
\hline $31-37$ & 1 & 5 \\
\hline $38-44$ & 1 & 5 \\
\hline $45-51$ & 2 & 10 \\
\hline$>52$ & 13 & 65 \\
\hline Total & 20 & 100 \\
\hline \multicolumn{3}{|l|}{ Pendidikan } \\
\hline SD & 7 & 35 \\
\hline SMP & 2 & 10 \\
\hline SMA & 5 & 25 \\
\hline DIPLOMA & 1 & 5 \\
\hline $\mathrm{S} 1$ & 5 & 25 \\
\hline Total & 20 & 100 \\
\hline \multicolumn{3}{|l|}{ Pekerjaan } \\
\hline Petani & 4 & 20 \\
\hline IRT & 6 & 30 \\
\hline Wiraswasta/perdagan & 5 & 25 \\
\hline \multicolumn{3}{|l|}{ gan } \\
\hline PNS & 4 & 20 \\
\hline Perawat & 1 & 5 \\
\hline Total & 20 & 100 \\
\hline
\end{tabular}

Berdasarkan Tabel 1 didapatkan hasil data karakteristik pasien paling banyak berjenis kelamin perempuan $(55 \%)$, berumur lebih dari 55 tahun $(65 \%)$, dengan tingkat pendidikan paling banyak adalah SD (35\%) dan pekerjaan paling banyak yaitu ibu rumah tangga (30\%).

Pada tabel 2 didapatkan data tentang sikap positif maupun negatif pasien terhadap penggunaan obat antihipertensi.

Tabel 2. Distribusi Berdasarkan Sikap

Responden

\begin{tabular}{ccc}
\hline Sikap & $\begin{array}{c}\text { Frekuensi } \\
(\mathbf{f})\end{array}$ & $\begin{array}{c}\text { Persentase } \\
(\boldsymbol{\%})\end{array}$ \\
\hline Negatif & 7 & 35 \\
Positif & 13 & 65 \\
\hline Total & 20 & 100 \\
\hline
\end{tabular}


Berdasarkan tabel 2 menunjukkan bahwa sikap responden pasien hipertensi sebagian besar memiliki sikap yang positif yaitu sebanyak 13 orang $(65 \%)$ dan $35 \%$ bersifat negatif. Hasil tersebut menggambarkan bahwa pasien yang memiliki sikap baik lebih banyak daripada pasien dengan sikap sedang.Sikap merupakan reaksi atau respon yang masih tertutup dari seseorang terhadap suatu stimulus atau objek (Notoadmodjo, 2012). Hasil penelitian ini dapat terlihat bahwa apabila pasien memiliki sikap yang baik dilaksanakan juga baik ataupun cukup baik. Lawrence Green menyatakan bahwa perilaku kesehatan akan dipengaruhi oleh beberapa faktor salah satunya sikap. Sikap yang dimiliki responden akan memberikan dampak pada kesehatan responden itu sendiri, pengalaman pribadi menjadi dasar dari yang akan membawa pengaruh terhadap kesehatannya (Heriyadi, 2017). Hal ini juga dipengaruhi oleh tingkat pendidikan dan pekerjaan yang dimiliki oleh pasien, rata-rata pendidikan pasien diatas SMA dan sebagian besar memiliki pekerjaan, hal ini dapat berpengaruh terhadap sikap pasien.

Pada tabel 3 didapatkan data tentang pengetahuan pasien hipertensi terhadap penggunaan obat antihipertensi.

Tabel 3. Distribusi Berdasarkan Pengetahuan Responden

\begin{tabular}{ccc}
\hline Pengetahuan & $\begin{array}{c}\text { Frekuensi } \\
(\mathbf{f})\end{array}$ & $\begin{array}{c}\text { Persentase } \\
(\mathbf{\%})\end{array}$ \\
\hline Sedang & 6 & 30 \\
Baik & 14 & 70 \\
\hline Total & $\mathbf{2 0}$ & $\mathbf{1 0 0}$ \\
\hline
\end{tabular}

Berdasarkan tabel 3 menunjukkan pengetahuan responden sebagian besar memiliki tingkat pengetahuan yang baik yaitu sebanyak 14 orang $(70 \%)$, sedangkan untuk tingkat pengetahuan sedang sebanyak 6 orang $(30 \%)$. Pasien umumnya menerima informasi pada saat konseling pada apoteker ketika pengambilan obat. Dengan demikian, perlu adanya peningkatan edukasi terkait penggunaan obat antihipertensi melalui promosi kesehatan. Dibutuhkan peran tenaga kesehatan seperti apoteker dalam memberikan program promosi kesehatan termasuk edukasi kepada masyarakat terkait penggunaan obat antihipertensi yang benar. Pengetahuan tentang terapi hipertensi yang memadahi secara langsung akan berdampak pada kepatuhan penggunaan obat antihipertensi (Sinuraya et al, 2017). Pengetahuan tentang terapi hipertensi juga didapatkan pasien dari tenaga teknis kefarmasian pada saat menjelaskan dan melakukan pelayanan pengobatan kepada pasien, selain dipengaruhi oleh tingkat pendidikan dan pekerjaan pasien. Sejalan dengan penelitian sebelumnya yang dilakukan oleh Taufik Haldi at all, hasilnya juga menunjukkan hal yang sama yaitu tingkat pengetahuan pendidikan pasien akan berhubungan dengan kepatuhan pasien dalam melakukan terapi Kesehatan.

Pada tabel 4 didapatkan data pasien yang patuh dan tidak patuh dalam menggunakan obat antihipertensi.

Tabel 4. Distribusi Berdasarkan Kepatuhan Responden

\begin{tabular}{ccc}
\hline Kepatuhan & $\begin{array}{c}\text { Frekuensi } \\
(\mathbf{f})\end{array}$ & $\begin{array}{c}\text { Persentase } \\
(\mathbf{\%})\end{array}$ \\
\hline Tidak patuh & 9 & 45 \\
Patuh & 11 & 55 \\
& & \\
\hline Total & $\mathbf{2 0}$ & $\mathbf{1 0 0}$ \\
\hline
\end{tabular}

Berdasarkan tabel 4 menunjukkan bahwa pasien yang patuh sebanyak 11 orang (85\%), sedangkan untuk yang tidak patuh sebanyak 9 orang (45\%). Hasil tersebut menunjukkan bahwa sebagian besar responden patuh dalam penggunaan obat antihipertensi. Kepatuhan dipengaruhi oleh beberapa faktor yang membuat kemampuan pasien untuk mengikuti perawatan secara optimal sering terganggu oleh beberapa penghalang, diantaranya: faktor sosial ekonomi, sistem perawatan kesehatan, karakteristik penyakit, terapi penyakit dan faktor yang terkait dengan pasien. Walaupun hasil yang didapat dalam penelitian ini lebih banyak pasien yang kepatuhannya baik daripada yang sedang, pasien tetap perlu diberikan informasi yang tepat terkait penggunaan obat sehingga dapat memberikan pengaruh yang besar terhadap pola pikir sikap pasien. Dengan begitu, pasien akan meminum obat dengan patuh sesuai indikasi, dosis, interval waktu minum obat antihipertensi (Mengendai et al, 2017).

Pada tabel 5 didapatkan nilai yang bermakna antara sikap terhadap kepatuhan pasien dalam menggunakan obat antihipertensi.

Tabel 5. Hubungan Sikap Pasien Hipertensi Terhadap Kepatuhan

\begin{tabular}{ccccccccc}
\hline \multirow{2}{*}{$\begin{array}{c}\text { Tingkat } \\
\text { Sikap }\end{array}$} & \multicolumn{2}{l}{$\begin{array}{l}\text { Kepatuhan Minum } \\
\text { Obat Anti Hipertensi }\end{array}$} & $\begin{array}{c}\text { p- } \\
\text { value }\end{array}$ & OR & & \\
\cline { 2 - 7 } & $\begin{array}{c}\text { Tidak } \\
\text { patuh }\end{array}$ & \multicolumn{2}{c}{ Patuh } & & Jumlah & & & \\
\hline Negatif & 6 & 85.7 & 1 & 14.3 & 7 & 100.0 & & \\
Positif & 3 & 23.1 & 10 & 76.9 & 13 & 100.0 & 0.005 & 20.000 \\
Total & 9 & 45.0 & 11 & 55.0 & 20 & 100.0 & & \\
\hline
\end{tabular}

Berdasarkan data dari tabel 5 mengenai hubungan sikap pasien terhadap kepatuhan pasien hipertensi di Rumah Sakit Islam Purwodadi diperoleh hasil bahwa responden yang mempunyai sikap kategori negatif sebanyak 7 orang dimana sebagian besar tidak patuh dalam minum obat antihipertensi yaitu sebanyak 6 orang $(85,7 \%)$, sebaliknya dari responden yang bersikap negative hanya terdapat 1 orang $(14,3 \%)$ saja yang patuh dalam minum obat antihipertensi. Sedangkan responden yang mempunyai tingkat sikap yang positif sebanyak 13 orang yang diketahui mempunya 
patuh yaitu sebanyak 10 orang $(76,9 \%)$ dan tingkat yang tidak patuh sebanyak 3 orang $(23,1 \%)$.

Sedangkan hasil uji Chi-Square didapatkan hasil nilai signifikansi yaitu $0,005<0,05$. Sehingga Ho ditolak dan dapat disimpulkan bahwa terdapat hubungan antara kelompok kategori sikap terhadap kepatuhan. Hal ini sejalan dengan teori yang dikemukakan oleh Lawrence Green, yang mana kepatuhan dipengaruhi oleh 3 faktor, yaitu faktor predisposisi, faktor pendorong, dan faktor pendukung. Sikap termasuk pada faktor predisposisi (Notoadmodjo, 2012). Berdasarkan hasil uji ChiSquare diperoleh nilai Odd Ratio (OR) sebesar 20,000 dengan Confidence Interval (CI 95\%) antara 1,676-238,630. Artinya pasien hipertensi di Rumah Sakit Islam Purwodadi yang tingkat sikap sedang beresiko 20,000 kali mempunyai kepatuhan kategori sedang dibandingkan yang mempunyai tingkat sikap kategori baik. Nilai OR dalam penelitian ini $>1$ ( bersifat resiko), artinya tingkat sikap sebagai faktor resiko kepatuhan minum obat antihipertensi di Rumah Sakit Islam Purwodadi

Tabel 6 didapatkan nilai yang bermakna antara pengetahuan terhadap kepatuhan pasien dalam menggunakan obat antihipertensi.

Tabel 6. Hubungan Pengetahuan Pasien Hipertensi Terhadap Kepatuhan

\begin{tabular}{|c|c|c|c|c|c|c|c|c|}
\hline \multirow{3}{*}{$\begin{array}{l}\text { Tingkat } \\
\text { Pengetahuan }\end{array}$} & \multicolumn{6}{|c|}{$\begin{array}{l}\text { Kepatuhan Minum Obat Anti } \\
\text { Hipertensi }\end{array}$} & \multirow{3}{*}{$\begin{array}{c}\text { p- } \\
\text { value }\end{array}$} & \multirow{3}{*}{ OR } \\
\hline & \multicolumn{2}{|c|}{$\begin{array}{l}\text { Tidak } \\
\text { patuh }\end{array}$} & \multicolumn{2}{|c|}{ Patuh } & \multicolumn{2}{|c|}{ Jumlah } & & \\
\hline & $\mathrm{F}$ & $\%$ & $\mathrm{~F}$ & $\%$ & $\mathrm{~F}$ & $\%$ & & \\
\hline Sedang & 5 & 83.3 & 1 & 16.7 & 6 & 100.0 & & \\
\hline Baik & 4 & 28.6 & 10 & 71.4 & 14 & 100.0 & 0.021 & 12.500 \\
\hline Total & 9 & 15.0 & 11 & 85.0 & 20 & 100.0 & & D \\
\hline
\end{tabular}

Berdasarkan data dari tabel 6 diperoleh hasil responden yang mempunyai tingkat pengetahuan kategori sedang sebanyak 6 orang dimana sebagian besar mempunyai kepatuhan minum obat antihipertensi kategori tidak patuh sebanyak 5 orang $(83,3 \%)$ lebih banyak daripada kategori patuh yaitu sebanyak 1 orang $(16,7 \%)$. Sedangkan hasil dari responden yang mempunyai tingkat pengetahuan yang baik sebanyak 14 orang dimana sebagian besar mempunyai tingkat kepatuhan yang patuh yaitu sebanyak 10 orang $(71,4 \%)$ dan tingkat yang tidak patuh sebanyak 4 orang $(28,6 \%)$.

Sedangkan hasil uji ChiSquaredidapatkan hasil nilai signifikansi yaitu $0,021<0,05$. Sehingga Ho ditolak dan dapat disimpulkan bahwa terdapat hubungan antara kelompok kategori pengetahuan terhadap kepatuhan. Hal ini sejalan dengan teori yang dikemukakan oleh Lawrence Green, yang mana kepatuhan dipengaruhi oleh 3 faktor, yaitu faktor predisposisi, faktor pendorong, dan faktor pendukung. Pengetahuan termasuk pada faktor predisposisi (Notoadmodjo, 2012). Berdasarkan hasil uji Chi-Square diperoleh nilai Odd Ratio (OR) sebesar 12,500 dengan Confidence Interval (CI 95\%) antara 1,089-143,432. Artinya pasien hipertensi di Rumah Sakit Islam Purwodadi yang tingkat pengetahuan sedang beresiko 12,500 kali mempunyai kepatuhan kategori sedang dibandingkan yang mempunyai tingkat pengetahuan kategori baik. Nilai OR dalam penelitian ini >1 ( bersifat resiko).

\section{KESIMPULAN}

Pada penelitian ini, sebagian besar responden memiliki pengetahuan yang baik dan sikap yang positif. Mengingat pengetahuan dapat mempengaruhi kepatuhan pasien dalam meminum obat, edukasi untuk meningkatkan pengetahuan sebaiknya terus dilakukan. Edukasi yang dilakukan meliputi gejala hipertensi, pengobatatan,dan pencegahannya, edukasi hendaknya juga memfokuskan pada manfaat patuh dalam meminum obat dalam pengobatan hipertensi sehingga sikap responden menjadi positif sehingga kepatuhan dapat meningkat.

\section{DAFTAR PUSTAKA}

Azwar, S. 2007. Sikap Manusia Teori dan Pengukurannya, edisi 2. Yogyakarta: Pustaka Pelajar.

Chobaniam A.V, Bakris, GL., Black, HR. 2003. Seventh Report of the Joint National Committe on Prevention, Detection, Evaluation, and Treatment of High Blood Pressure: Hypertension 2003: 42 (6): $1206-1252$.

Depkes RI 2012, Riset Kesehatan Dasar, Jakarta: Badan Penelitian Dan Pengembangan Kesehatan. Kementrian Kesehatan Republik Indonesia.

Depkes RI. 2006. Pharmaceutical Care Untuk Penyakit Hipertensi. Jakarta: Departemen Kesehatan RI.

Gama, IK, Sarmadi, TW, Harini, I 2014, 'Faktor penyebab ketidakpatuhan kontrol penderita hipertensi, Jurnal Keperawatan Politeknik Kesehatan Denpasar, 2(4), pp. 1-8.

Gunawan, L. 2001. Hipertensi. Jakarta: PT.Gramedia.

Heriyadi, Hasballah, K, Tahlil, T 2017, 'Pengetahuan, sikap, dan perilaku diet hipertensi lansia di Aceh', Jurnal Ilmu Keperawatan, 6(1), pp. 1-3.

Haldi, T, Pristianty, L, Hidayati, IR 2019,'Hubungan pengetahuan dan sikap pasien hipertensi terhadap kepatuhan penggunaan obat amlodipin di Puskesmas Arjuno Kota Malang'.

Marliani, L., Tantan S. 2007. 100 Question \& Answer : Hipertensi. Jakarta: PT Elex Media Komputindo. 
Mangkunegara, Prabu Anwar. 2002. Perilaku Konsumen. Edisi Revisi. Cetakan Kedua. PT. Refika Aditama Bandung.

Notoatmodjo, S. 2003. Pendidikan dan Perilaku Kesehatan. Jakarta: Rineka Cipta.

Notoatmodjo, S 2012, Promosi Kesehatan dan Perilaku Kesehatan, Jakarta: PT Rineka Cipta.

Nugroho, A. E. 2012. Farmakologi Obat-obat Penting dalam Pembelajaran Ilmu Farmasi dan Dunia Kesehatan. Yogyakarta: Pustaka Pelajar.

Sinuraya, RK, Dika, PD, Irma, M, Ajeng, D 2018, 'Tingkat kepatuhan pengobatan pasien hipertensi di fasilitas kesehatan tingkat pertama di kota Bandung', Jurnal
Farmasi Klinik Indonesia, 7(2), pp. 124- 133.

Soenarta, AA, Erwinanto, Mumpuni, S, Rossana, B, Nani, HAA 2015, Pedoman Tatalaksana Hipertensi Pada Penyakit Kardiovaskuler, Edisi I, Surabaya: Perhimpunan Dokter Spesialis Kardiovaskular Indonesia.

Soeparman, dkk., 1994. Ilmu Penyakit Dalam Jilid II. Jakarta: Balai penerbit FK UI.

Stephen J, Maxine A, McPhee. 2001. Medical Diagnosis \& Treatment. Amerika Serikat: The McGraw- Hill Companies.

World Health Organization. 1988. Education for Health, a manual on health education in primary health care. Geneva: Word Health Organization. 